\title{
Sources of shared variability of muscle, fat and bone weight distribution in New Zealand White rabbits
}

\author{
Karima A. SHAHIN* \\ Department of Animal production, Faculty of Agriculture, Ain Shams University, \\ PO Box 68, Hadayek Shoubra, 11241 Cairo, Egypt
}

(Received 1 February 2000; accepted 12 February 2001)

\begin{abstract}
A factor analysis with a varimax rotation was applied to 17 highly intercorrelated muscling, fatness and bone traits on 72 male New Zealand White rabbits to disclose the main sources of shared variability, deduce the factors that describe muscle, fat and bone distribution and predict total carcass muscle, fat and total carcass bone from orthogonal muscling, fatness and bone traits. Muscle, fat and bone weight distribution appeared to be controlled by common and unique factors. The communalities ranged from 0.38 (neck bone) to 0.91 (hind leg muscle) and the uniqueness (special size factors) made the remaining variances. The shared variability of structural tissues (muscle and bone) was higher than that of fatty tissue. Our findings indicate that most of the common variability (74\%) in muscle, fat and bone weight distribution can be accounted for by factors representing fatless, fatness, neck muscle and fat (boneless neck) factors. Differences and similarities between rabbits and other meat-producing species (Pekin ducklings and Japanese quail) in factors describing variations in muscling, fatness and bone traits are discussed. Independent muscling, fatness and bone traits derived from factor analysis accounted for $95 \%, 97 \%$ and $95 \%$ of the variation in total carcass muscle, total carcass fat and total carcass bone, respectively.
\end{abstract}

factor analysis / tissue variations / rabbits / estimation / multicollinearity

Résumé - Sources de variabilité commune dans la répartition pondérale des muscles, du gras et des os chez le lapin New Zealand White. Une analyse factorielle utilisant une rotation varimax a été appliquée à 17 variables musculaires, adipeuses et squelettiques mesurées sur 72 lapins de race New Zealand White afin (i) d'identifier les principales sources de variabilité commune, (ii) de déterminer les facteurs contrôlant la répartition des muscles, du gras et des os et (iii) de prédire la masse totale de muscles, de gras et d'os de la carcasse à partir des caractéristiques orthogonales. La répartition pondérale des muscles, du gras et des os semble à la fois contrôlée par des facteurs communs et des facteurs spécifiques. Les parts de variance dues aux facteurs communs sont comprises entre 0,38 (os du cou) et 0,91 (muscle des pattes postérieures) et les facteurs uniques (facteurs spécifiques du format) font le complément à 1 . La variabilité commune des tissus structuraux (muscles et os) a été plus élevée que celle des tissus adipeux. Nos résultats indiquent que l'essentiel de la variabilité (74 \%) de la répartition pondérale des muscles, du gras et des os peut être attribué à trois facteurs

* Correspondence and reprints 
représentant les parties maigres (I), le gras (II), les muscles et le gras du cou (sans os, III). Les différences et les similitudes des facteurs décrivant la variation de ces caractéristiques musculaires, adipeuses et osseuses entre les lapins et d'autres espèces à viande (canetons de Pékin et caille japonaise) sont discutées. Les données de muscles, de gras et d'os dérivées de l'analyse factorielle expliquent, respectivement, $95 \%, 97 \%$ et $95 \%$ de la variabilité de la masse totale musculaire, adipeuse et squelettique de la carcasse.

analyse factorielle / composition corporelle / lapin / multicollinéarité

\section{INTRODUCTION}

With an increasing demand for lean meat and growing discrimination against fat, more interest is focused on rabbits in order to fulfill this interest. Rabbit carcasses are characterized by the desirable distribution of their total muscle between different meat cuts. At their prevailing market ages, rabbits compared with other meat- producing species have proportionately more total carcass muscle occurring in the loin and hind leg, more muscle and less fat (especially subcutaneous fat) in the carcass and less cholesterol in their meat [3, 13, 23].

The correlation between muscling, fatness and bone traits may be different if these traits are treated as bivariates rather than as multivariates. Since carcass traits are both genetically and phenotypically intercorrelated $[2,10,14,17-20,33,34,36]$, the analysis of these traits should considered the interdependence among predictors (multicollinearity).

Independent 'orthogonal' factor scores derived from factor analysis have been used advantageously as predictors of total carcass muscle, fat and bone and other performance traits [26, 28-30] and as a selection criterion for the genetic improvement of muscle weight distribution [27]. The objectives of this study were to disclose the main sources of shared variability, deduce factors that describe muscle, fat and bone distribution in New Zealand White rabbits and to estimate carcass muscling, fatness and bone utilizing orthogonal carcass traits derived from factor analysis.

\section{MATERIALS AND METHODS}

Seventy-two males New Zealand White rabbits, aged 12 weeks with 1976 g average body weight at slaughter were used in this study. The animals were slaughtered by severing the carotid artery and jugular veins. The feet and shanks were removed at the tibio-tarsus joint and the head at the atlantooccipital articulation. After dressing, carcasses were stored at $-20^{\circ} \mathrm{C}$. Prior to cutting and dissection, the carcasses were thawed for approximately $18 \mathrm{~h}$ at $5{ }^{\circ} \mathrm{C}$ while remaining in their bags. The right sides were divided into the following meat cuts based on their anatomical location: hind leg, loin, abdominal wall, breast, fore leg and neck. In each, cut subcutaneous fat, intermuscular fat, muscle and bone were dissected and weighed. The weight of muscle and fat was referred to as the boneless 'meat' weight and the weight of muscle and bone was referred to as the fatless 'fat-free' weight. The sum of these parts for all the meat cuts gave total side muscle (TSM), total side bone (TSB) and total side skin plus subcutaneous fat and total side intermuscular fat. The sum of the skin plus subcutaneous fat and intermuscular fat was referred to as the total side fat (TSF).

The data were subject to a factor analysis procedure [25]. The main source of shared variation among the interdependence of muscling, fatness and bone traits $(p)$ was expressed in terms of fewer mutually uncorrelated common factors $\mathrm{F} 1, \mathrm{~F} 2, \ldots, \mathrm{Fq}$ (where $q<p$ ) than the original measurements 
$[5,7]$. The first factor contained the greatest portion of the original variation and in a morphometric application of factor analysis, it was designated as a general size factor. Subsequent factors were mutually orthogonal to the preceding ones and to one another and contained less variation.

The model used was as follows:

$$
\mathrm{X}=\Lambda \mathrm{F}+\mathrm{U}
$$

where $\mathrm{X}=a p \times 1$ is a vector of observational variables; $\Lambda=a p \times q$ a matrix of factor loading 'factor-variate correlations, the degree of correlation of the variable with the factor' (the pattern matrix); $\mathrm{F}=a q \times 1$ a vector of factors (non-observable); and $\mathrm{U}=a p \times 1 a$ vector of the specific 'unique' factor.

The total variance of a variable was equal to unity and can be written as the sum of common variance 'communalities' and unique variance 'uniqueness'. The communality represented the portion of the variable variance accounted for by all common factors and the uniqueness represented the portion of the variable variance not ascribable to its correlation with other variables.

Preliminary multiple regression analyses using the COLLIN option were used to detect collinearity (collinearity diagnostics) in the explanatory variables. A small characteristic root (eigen value, $\lambda$ ) is an indicator of multicollinearity. A build up stepwise multiple regression was used to predict total side muscle weight, total side fat weight and total side bone weight from the orthogonal muscling, fatness and bone traits derived from factor analysis. Attaining the 5\% level of significance was the predetermined criterion for entering the independent variables. Their sequence of retention followed a descending order for the amount of explained variance. The program terminated when the last independent variable entering the equation had an insignificant regression coefficient.

\section{RESULTS AND DISCUSSION}

\subsection{Original 'non-independent' variables}

Table I presents the means, standard deviations, coefficient of variability and ranges for live weight and muscle, fat and bone traits. Total side muscle ranged from 235 to $607 \mathrm{~g}$ with a mean of $368 \mathrm{~g}$, total side fat ranged from 4 to $28 \mathrm{~g}$ with a mean of $15 \mathrm{~g}$ and total side bone ranged from 52 to $96 \mathrm{~g}$ with a mean of $70 \mathrm{~g}$. Muscle, bone and fat relative to live body weight were estimated at $37 \%, 7 \%$ and $1.5 \%$ (Tab. I), $34.1 \%$, $7.5 \%$ and $1.3 \%$ [32], 27.9\%, $11.8 \%$ and $15.9 \%$ for Pekin ducklings [26] and $39.7 \%$, $9.62 \%$ and $5.61 \%$ for the Japanese quail [28]. Lukefahr et al. [18] found that muscle, as a percentage of live weight in the Flemish Giant was higher than that in NZW (33.1\% vs. $26.5 \%)$. The muscle content of rabbits comprised approximately $81 \%$ (Tab. I), 79\% [35] and 85\% [22] of the carcass. The average fat percentage in the carcass in the present study was $3.2 \%$; corresponding value reported by Parigi-Bini [22] was $4.2 \%$ and that reported by Niedźwiadek [20] was $5.6 \%$. The average boneless percentage in the carcass in the present study was slightly lower than that reported by El-Handaway et al. [9] (84.4\% vs. $86.4 \%$, respectively). The average carcass muscle: bone ratio in the present study was lower than that reported by Ouhayoun [21] (5.3 vs. 6.8 , respectively).

The muscle: bone ratio or 'fleshiness', for various parts of the carcass are also shown in Table I. The muscle: bone ratio in the loin ranged from 4.90 to 10.36 with a mean of 7.13; the corresponding value reported by Lukefahr and Ozimba [18] was 4.48. Varewyck et al. [33] reported a ratio of 6.30. The relatively high muscle: bone ratio in rabbits is due to a greater development of muscle as well as a lesser development of the skeleton (i.e. finer bones).

Hind leg muscle and loin muscle accounted for $38.5 \%$ and $20.8 \%$ respectively, 
Table I. Means, standard deviations (SD), coefficient of variability (CV\%) and minimum and maximum values for live and carcass traits in New Zealand White rabbits.

\begin{tabular}{|c|c|c|c|c|}
\hline & Mean & $\mathrm{SD}$ & $\mathrm{CV} \%$ & Range \\
\hline Live weight (g) & 1975.55 & 364.19 & 18.43 & $1340-2842$ \\
\hline Carcass weight (g) & 903.89 & 200.82 & 22.22 & $598.00-1445.80$ \\
\hline Total carcass muscle (g) & 735.45 & 173.10 & 23.54 & $470.60-1213.00$ \\
\hline Total carcass fat $(\mathrm{g})$ & 29.27 & 12.28 & 41.95 & $8.60-56.00$ \\
\hline Total carcass bone (g) & 139.17 & 23.54 & 16.91 & $103.60-189.00$ \\
\hline \multicolumn{5}{|l|}{ Percentage of live weight } \\
\hline Total muscle & 37.02 & 3.41 & 9.21 & $29.82-43.83$ \\
\hline Total fat & 1.47 & 0.50 & 34.01 & $0.44-2.37$ \\
\hline Total bone & 7.11 & 0.74 & 10.41 & $5.41-9.27$ \\
\hline \multicolumn{5}{|c|}{ Percentage of carcass weight } \\
\hline Total muscle & 81.14 & 1.57 & 1.93 & $77.62-4.70$ \\
\hline Total fat & 3.22 & 1.07 & 33.38 & $0.96-5.01$ \\
\hline Total bone & 15.65 & 1.69 & 10.79 & $12.14-19.73$ \\
\hline Fatless carcass & 96.78 & 1.07 & 1.11 & 94.99-99.04 \\
\hline Boneless carcass & 84.35 & 1.69 & 2.00 & $80.27-87.86$ \\
\hline \multicolumn{5}{|l|}{ Percentage of total muscle } \\
\hline Hind leg & 38.47 & 1.47 & 3.82 & $35.85-45.14$ \\
\hline Loin & 20.79 & 1.38 & 6.64 & $18.05-24.04$ \\
\hline Abdominal wall & 8.40 & 0.97 & 11.55 & $6.84-11.18$ \\
\hline Breast & 16.86 & 1.45 & 8.60 & $13.48-20.25$ \\
\hline Fore leg & 11.79 & 1.18 & 10.01 & $9.12-16.39$ \\
\hline Neck & 3.67 & 1.39 & 37.87 & $1.47-7.18$ \\
\hline \multicolumn{5}{|l|}{ Percentage of total fat } \\
\hline Hind leg & 23.43 & 7.25 & 30.94 & $5.26-35.97$ \\
\hline Loin & 18.46 & 6.58 & 35.64 & $2.88-32.54$ \\
\hline Abdominal wall & 10.62 & 6.64 & 62.52 & $1.18-44.19$ \\
\hline Breast & 21.40 & 7.89 & 36.87 & $6.67-43.48$ \\
\hline Fore leg & 14.36 & 6.50 & 45.26 & $6.73-31.03$ \\
\hline Neck & 11.72 & 5.82 & 49.66 & $1.57-26.56$ \\
\hline \multicolumn{5}{|l|}{ Percentage of total bone } \\
\hline Hind leg & 40.53 & 2.27 & 5.60 & $32.09-44.93$ \\
\hline Loin & 15.44 & 1.36 & 8.81 & $12.09-18.76$ \\
\hline Breast & 20.89 & 2.87 & 13.74 & $14.57-26.94$ \\
\hline Fore leg & 17.38 & 1.14 & 6.56 & $14.94-20.27$ \\
\hline Neck & 5.76 & 1.21 & 21.01 & $3.69-8.64$ \\
\hline \multicolumn{5}{|l|}{ Muscle: bone ratio } \\
\hline Hind leg & 5.00 & 0.67 & 13.46 & $3.90-6.51$ \\
\hline Loin & 7.13 & 1.20 & 16.80 & $4.90-10.36$ \\
\hline Breast & 4.33 & 0.91 & 21.01 & $2.53-6.20$ \\
\hline Fore leg & 3.56 & 0.50 & 14.00 & $2.70-5.00$ \\
\hline Neck & 3.40 & 1.26 & 37.10 & $1.29-7.09$ \\
\hline Whole carcass & 5.25 & 0.65 & 12.46 & $3.97-6.98$ \\
\hline
\end{tabular}


of total carcass muscle (Tab. I). The corresponding values reported by Deltoro and López [8] were $38.4 \%$ and $19.3 \%$. Hind leg bone and breast bone accounted for $40.5 \%$ and $20.9 \%$ respectively, of the total carcass bone. Hind leg fat and breast fat accounted for $23.4 \%$ and $21.4 \%$ respectively, of total carcass fat weight. In the Japanese quail, hind leg muscle, bone and fat accounted for $33.30 \%, 39.41 \%$ and $29.10 \%$ of the total carcass muscle, total carcass bone and total carcass fat, respectively [28]. The corresponding values in Pekin ducklings were $33.98 \%, 32.47 \%$ and $24.68 \%$ [29]. It appears that rabbits as compared with the above mentioned meat-producing species have more muscle and bone and less fat occurring in the hind leg. Similarly, in the lamb, Jackson [12] found that the gigot (hind leg) muscle, bone and fat account for $38.7 \%$, $34.8 \%$ and $29.1 \%$ of the total weights of the corresponding tissues of the carcass.

The coefficient of variability of bone traits was lower than that of flesh traits which in turn was lower than that of fat traits. Within the same anatomical region, the variability of muscle and bone was smaller than that of fat (Tab. I).

\subsection{Their relationship with side muscle, total side fat and total side bone}

The weight of muscle, fat or bone in most cuts appeared to be highly correlated with the total weight of the corresponding tissue in the carcass (Tab. II). Niedźwiadek [19, 20] has reported similar findings. Total carcass fat had the highest correlation (0.82) with hind leg fat weight and the lowest correlation $(0.53)$ with neck fat weight. The correlation between hind leg muscle weight and TSM was 0.99, that between hind leg bone and TSB was 0.95 , while that between hind leg fat weight and TSF was 0.82 . The correlation coefficient between the weight of the muscle in the carcass and the weight of the hind leg muscle in this study was similar $(r=0.98)$ to that reported by Bochno et al. [4]. Varewyck and Bouquet [32] obtained a correlation of 0.93 between the fat percentage in the loin and in the whole carcass. Muscle and bone in various cuts other than the neck were highly correlated. The correlations between muscling and bone traits were higher than those between muscling and fatness and between fatness and bone traits. Among all 17 traits, neck muscle and neck fat seemed to be the least dependent on the others. These two traits were poorly (less closely) correlated with most muscling, fatness and bone traits, while the neck bone was moderately correlated with muscling and bone traits.

A number of equations that predict major carcass tissues or muscle: bone ratios in rabbits have been developed utilizing live animal measurements and carcass measurements. Niedźwiadek [19] constructed an equation using carcass weight, carcass length, hind part weight, and hind part lean to predict total carcass lean. Blasco et al. [2] developed prediction equations utilizing external measurements and the dissectable components of the hind leg for predicting the muscle: bone ratio in the carcass. Lukefahar et al. [16] constructed an equation for the prediction of meat weight from body weight and loin width. This equation explained $74 \%$ of the variation in total meat weight. Lewzcuk et al. [15] used slaughter weight and loin width as predictors of total carcass lean. For the estimation of total carcass bone, they used an equation incorporating slaughter weight and head width.

The separable muscle in the hind leg was associated with $97 \%$ of the total variation in TSM in the rabbit. An identical $R^{2}$ has been reported by Blasco et al. [2]. Slight improvements in the accuracy of the TSM estimates appeared with a stepwise addition of the weight of muscle occurring in the breast and loin. It should be mentioned that in relatively small sized species such as rabbits, sheep and pigs, the dissectible components (muscle, fat and bone) from the leg and loin, are used most frequently as 
Table II. Coefficients of correlation between ${ }^{\dagger}$ muscling, fatness and bone traits in New Zealand White rabbits.

LW TSM TSF TSB HLM FLM LM

Live weight (LW)

Total side muscle (TSM) $\quad 0.92$

Total side fat (TSF) $\quad 0.56 \quad 0.56$

Total side bone (TSB) $\quad 0.82 \quad 0.87 \quad 0.33$

Hind leg muscle (HLM) $\quad 0.90 \quad 0.99 \quad 0.53 \quad 0.86$

Fore leg muscle (FLM) $\quad 0.85 \quad 0.91 \quad 0.43 \quad 0.87 \quad 0.88$

$\begin{array}{lllllll}\text { Loin muscle (LM) } & 0.88 & 0.97 & 0.56 & 0.81 & 0.94 & 0.85\end{array}$

$\begin{array}{llllllll}\text { Breast muscle (BM) } & 0.90 & 0.95 & 0.53 & 0.84 & 0.92 & 0.86 & 0.88\end{array}$

Abdominal wall muscle

$\begin{array}{lllllllll}\text { (ABM) } & 0.91 & 0.90 & 0.59 & 0.77 & 0.88 & 0.83 & 0.87 & 0.85\end{array}$

$\begin{array}{llllllllll}\text { Neck muscle (NM) } & 0.03 & 0.21 & 0.30 & 0.10 & 0.16 & 0.09 & 0.21 & 0.22 & -0.04\end{array}$

$\begin{array}{lllllllllll}\text { Hind leg bone (HLB) } & 0.77 & 0.85 & 0.29 & 0.95 & 0.85 & 0.83 & 0.79 & 0.82 & 0.78 & 0.15\end{array}$

$\begin{array}{llllllllllll}\text { Fore leg bone (FLB) } & 0.77 & 0.79 & 0.34 & 0.94 & 0.77 & 0.80 & 0.73 & 0.75 & 0.69 & 0.10 & 0.87\end{array}$

$\begin{array}{lllllllllllll}\text { Loin bone (LB) } & 0.79 & 0.83 & 0.32 & 0.92 & 0.82 & 0.83 & 0.78 & 0.76 & 0.79 & 0.03 & 0.86 & 0.87\end{array}$

$\begin{array}{lllllllllllllll}\text { Breast bone (BB) } & 0.71 & 0.71 & 0.25 & 0.86 & 0.69 & 0.72 & 0.65 & 0.72 & 0.68 & -0.02 & 0.70 & 0.75 & 0.71\end{array}$

$\begin{array}{lllllllllllllll}\text { Neck bone (NB) } & 0.45 & 0.55 & 0.20 & 0.89 & 0.53 & 0.54 & 0.54 & 0.51 & 0.41 & 0.32 & 0.54 & 0.50 & 0.51 & 0.38\end{array}$

$\begin{array}{llllllllllllllll}\text { Hind leg fat (HLF) } & 0.41 & 0.46 & 0.82 & 0.30 & 0.45 & 0.31 & 0.43 & 0.47 & 0.46 & 0.24 & 0.33 & 0.27 & 0.28 & 0.20 & 0.12\end{array}$

$\begin{array}{lllllllllllllllll}\text { Fore leg fat (FLF) } & 0.46 & 0.43 & 0.69 & 0.37 & 0.39 & 0.45 & 0.49 & 0.35 & 0.45 & 0.06 & 0.30 & 0.40 & 0.36 & 0.33 & 0.23 & 0.58\end{array}$

$\begin{array}{lllllllllllllllllll}\text { Loin fat (LF) } & 0.32 & 0.39 & 0.64 & 0.09 & 0.37 & 0.26 & 0.37 & 0.40 & 0.37 & 0.21 & 0.11 & 0.10 & 0.06 & 0.07 & -0.06 & 0.45 & 0.20\end{array}$

$\begin{array}{lllllllllllllllllllll}\text { Breast fat }(\mathrm{BF}) & 0.55 & 0.48 & 0.77 & 0.34 & 0.44 & 0.42 & 0.48 & 0.45 & 0.53 & 0.24 & 0.22 & 0.34 & 0.31 & 0.41 & 0.28 & 0.42 & 0.47 & 0.32\end{array}$

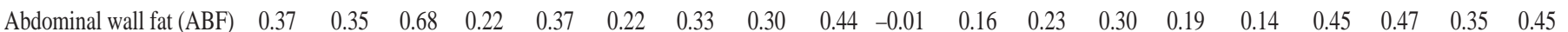

$\begin{array}{llllllllllllllllllllll}\text { Neck fat }(\mathrm{NF}) & 0.08 & 0.11 & 0.53 & -0.09 & 0.08 & -0.04 & 0.12 & 0.09 & 0.08 & 0.55 & -0.04 & -0.05 & -0.12 & -0.17 & 0.01 & 0.37 & 0.04 & 0.48 & 0.36 & 0.14\end{array}$

0.232 required for significant at $5 \%$ and 0.302 required for significant at $1 \%$. 
predictors of the same components in the whole carcass $[1,6]$.

For TSB, $90 \%$ of the variability was explained by the hind leg bone. Multiple correlation showed that $R^{2}$ increased from 0.97 to 0.99 and the residual standard deviation of the estimate decreased from $1.96 \mathrm{~g}$ to $1.26 \mathrm{~g}$ with a stepwise addition of the breast bone and loin bone.

Hind leg fat alone accounted for $66 \%$ of the variation in TSF. The results of a stepwise multiple regression showed that $R^{2}$ increased from 0.89 to 0.95 and the residual standard deviation of the estimate decreased from $2.05 \mathrm{~g}$ to $1.43 \mathrm{~g}$ with the stepwise addition of breast fat and loin fat. It appeared that the breast fat and loin fat made a distinct improvement in $\mathrm{R}^{2}$ when added to the hind leg fat.
These results indicate that TSM, TSB and TSF can be predicted with a very high degree of accuracy from respective tissues in the hind leg, breast and loin. Caution should, however, be exercised since the presence of multicollinearity among independent variables may limit their usefulness as estimators.

\subsection{Varimax rotated 'independent' factors}

\subsubsection{Their interpretation}

Three common factors (one for fatless 'fat-free', one for fat, and the other for boneless neck) were identified, contributing to $74 \%$ of the variability of the original 17 variables, leaving $26 \%$ to the 17 'unique' factors (Tab. III).

Table III. The explained variation associated with rotated factor analysis along with communalities and a unique factor for each variable. Correlation between factor score coefficients and original variables in New Zealand White rabbits.

\begin{tabular}{lccccc}
\hline & \multicolumn{3}{c}{ Rotated common factors } & & \\
\cline { 2 - 4 } & I & II & III & Communalities & $\begin{array}{c}\text { Unique } \\
\text { factor }\end{array}$ \\
\hline Hind leg muscle & 0.870 & 0.382 & 0.107 & 0.914 & 0.086 \\
Fore leg muscle & 0.889 & 0.261 & 0.002 & 0.859 & 0.141 \\
Loin muscle & 0.832 & 0.401 & 0.156 & 0.877 & 0.123 \\
Breast muscle & 0.846 & 0.352 & 0.168 & 0.868 & 0.132 \\
Abdominal wall muscle & 0.752 & 0.537 & -0.064 & 0.857 & 0.143 \\
Neck muscle & 0.120 & 0.005 & 0.764 & 0.599 & 0.401 \\
Hind leg bone & 0.926 & 0.075 & 0.058 & 0.867 & 0.133 \\
Fore leg bone & 0.872 & 0.154 & -0.029 & 0.785 & 0.215 \\
Loin bone & 0.892 & 0.184 & -0.115 & 0.842 & 0.158 \\
Breast bone & 0.763 & 0.176 & -0.155 & 0.637 & 0.363 \\
Neck bone & 0.592 & -0.003 & 0.183 & 0.384 & 0.616 \\
Hind leg fat & 0.183 & 0.714 & 0.220 & 0.592 & 0.408 \\
Fore leg fat & 0.287 & 0.575 & -0.056 & 0.417 & 0.583 \\
Loin fat & 0.068 & 0.538 & 0.335 & 0.406 & 0.594 \\
Breast fat & 0.287 & 0.555 & 0.210 & 0.435 & 0.565 \\
Abdominal wall fat & 0.116 & 0.697 & -0.049 & 0.501 & 0.499 \\
Neck fat & -0.132 & 0.328 & 0.753 & 0.691 & 0.309 \\
\% of variance & 50.91 & 14.51 & 8.61 & & \\
Description & Fatless & Fatness & Boneless & & \\
& & & neck & & \\
\hline
\end{tabular}


The first factor (I, general size 'fatless') was characterized by high positive loadings (factor-variate correlations) on all muscling and bone traits (Tab. III, and Fig. 1). The variables associated with the hind leg bone and loin bone had the highest loadings, followed by the fore leg muscle and hind leg muscle. This factor accounted for $50.9 \%$ of the variation of the original variables and is fatness independent.

The second factor (II, fatness) gave relatively little weight to fat in the neck region and accounted for an additional $14.5 \%$ of the total variation. Variables associated with hind leg fat had the highest loading, followed by those associated with abdominal wall fat and fore leg fat. This factor presented a pattern of variation in fatness independent of muscling and bone (fatless).

The third factor (III, boneless neck) accounted for $8.6 \%$ of the total variation with high loadings on the neck muscle and fat (Fig. 1). The neck structures and functions enable the animal to maintain its balance by shifting the center of gravity during running and providing a means of locomotion. It seems that in the rabbit, the neck muscle and other muscles in the carcass were subject to independent determination. Tanner and Burt [31] re-analyzed the rabbit measurements of Wright [37] by factor analysis to identify factors that control body weight and bone measurements. They found a basic 'general size' factor and that the factors for head and limbs controlled these traits. The limbs depend on a common factor, not operative on the head.

In brief, most of the common variability in muscling, fatness and bone traits could be accounted for by factors representing fatless (muscle, bone), fatness, neck muscle and fat (boneless neck).

It was our interest to examine how rabbit factors which describe variations in

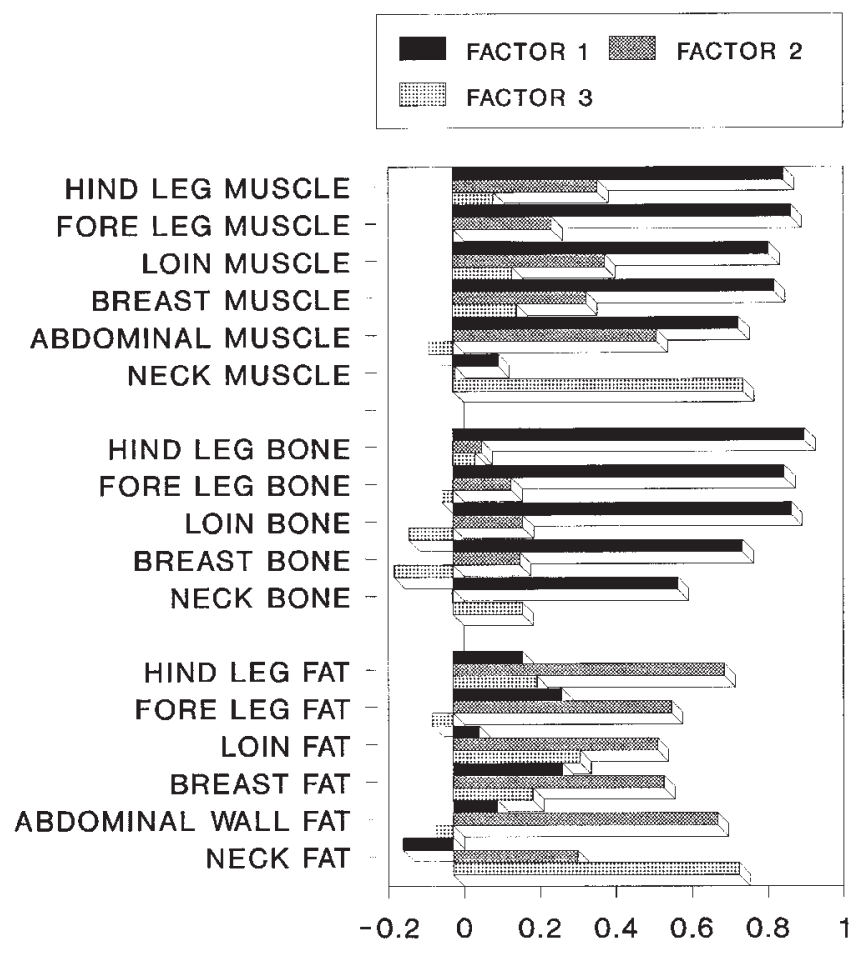

Figure 1. Correlation between factor score coefficients and original muscling, fatness and bone traits in New Zealand White rabbits. 
muscle, fat and bone weight distribution differ from those of other meat-producing species (i.e. Pekin ducklings and Japanese quail) (Tabs. IV and V). In these tables some differences and similarities among these species are worth noting. It was found that, most of the common variability $(74.3 \%)$ of the above mentioned traits in Pekin ducklings could be accounted for by factors representing fatness (which explained $45.0 \%$ of the total variability), muscling (which explained 20.9\%) and bone (which explained $8.5 \%$ ). While in the Japanese quail most of the common variability (66.9\%) in muscling, fatness and bone traits could be accounted for by factors representing boneless (muscle + fat) (which explained 50.5\%), bone (which explained $10.7 \%$ ) and wing fat (which explained 5.6\%). The proportion of variation which was explained by structural tissues (muscle and bone) tended to be higher in NZW rabbits than in Pekin ducklings ( 50.9 vs. $29.3 \%$ ), while the proportion explained by fatness was higher in Pekin ducklings than in NZW rabbits (45.0 vs. 29.0). In NZW rabbits, fatless and fatness traits were subject to independent determination, while in the Japanese quail, boneless and bone traits were subject to independent determination. In Pekin ducklings, the factor that acts on fatness is different from those acting on muscling and bone traits. The way the weight is distributed over the body and the genetic adaptation to physiological needs might be the reasons for differences in these factors [11].

Table IV. The explained variation associated with rotated factor analysis along with communalities and a unique factor for each variable. Correlation between factor score coefficients and original variables in Pekin ducklings ${ }^{\dagger}$.

\begin{tabular}{lccccc}
\hline & \multicolumn{3}{c}{ Common factors } & & \\
\cline { 2 - 4 } & I & II & III & Communality & $\begin{array}{c}\text { Unique } \\
\text { factor }\end{array}$ \\
\hline Drumstick muscle & 0.275 & 0.666 & 0.396 & 0.676 & 0.324 \\
Thigh muscle & 0.114 & 0.711 & 0.418 & 0.692 & 0.308 \\
Breast muscle & 0.092 & 0.921 & 0.122 & 0.871 & 0.129 \\
Wing muscle & 0.060 & 0.844 & 0.271 & 0.790 & 0.210 \\
Neck muscle & 0.417 & 0.319 & 0.538 & 0.566 & 0.434 \\
Drumstick bone & 0.025 & 0.154 & 0.524 & 0.299 & 0.701 \\
Thigh bone & 0.091 & 0.411 & 0.665 & 0.619 & 0.381 \\
Breast bone & 0.264 & 0.546 & 0.480 & 0.598 & 0.402 \\
Wing bone & 0.014 & 0.463 & 0.665 & 0.660 & 0.340 \\
Neck bone & 0.680 & -0.251 & 0.546 & 0.823 & 0.177 \\
& & & & & 0.623 \\
Drumstick fat & 0.786 & -0.072 & -0.018 & 0.677 \\
Thigh fat & 0.805 & 0.266 & 0.046 & 0.720 & 0.280 \\
Breast fat & 0.897 & 0.246 & 0.079 & 0.872 & 0.128 \\
Wing fat & 0.759 & 0.209 & 0.257 & 0.686 & 0.314 \\
Neck fat & 0.853 & 0.107 & 0.081 & 0.745 & 0.255 \\
\% of variance & 44.95 & 20.87 & 8.46 & & \\
Description & Fatness & Muscling & Bone & & \\
\hline
\end{tabular}

$\dagger$ Data from Shahin [26, 29]. 
Table $\mathbf{V}$. The explained variation associated with rotated factor analysis along with communalities and a unique factor for each variable. Correlation between factor score coefficients and original variables in the Japanese quail ${ }^{\dagger}$.

\begin{tabular}{lcccccc}
\hline & \multicolumn{3}{c}{ Common factors } & & \\
\cline { 2 - 4 } & I & II & III & Communality & $\begin{array}{c}\text { Unique } \\
\text { factor }\end{array}$ \\
\hline Drumstick muscle & 0.800 & 0.321 & 0.279 & 0.831 & 0.169 \\
Thigh muscle & 0.796 & 0.356 & 0.343 & 0.877 & 0.123 \\
Breast muscle & 0.841 & 0.342 & 0.273 & 0.899 & 0.101 \\
Wing muscle & 0.871 & 0.307 & 0.001 & 0.853 & 0.147 \\
Neck muscle & 0.620 & 0.275 & 0.367 & 0.594 & 0.406 \\
Drumstick bone & 0.163 & 0.880 & 0.092 & 0.809 & 0.191 \\
Thigh bone & 0.203 & 0.797 & 0.214 & 0.722 & 0.278 \\
Breast bone & 0.333 & 0.639 & 0.105 & 0.530 & 0.470 \\
Wing bone & 0.287 & 0.813 & 0.142 & 0.764 & 0.236 \\
Neck bone & 0.358 & 0.606 & 0.119 & 0.511 & 0.489 \\
Drumstick fat & 0.371 & 0.277 & 0.446 & 0.413 & 0.587 \\
Thigh fat & 0.531 & 0.138 & 0.426 & 0.483 & 0.517 \\
Breast fat & 0.461 & 0.171 & 0.313 & 0.340 & 0.660 \\
Wing fat & 0.277 & 0.173 & 0.777 & 0.711 & 0.289 \\
Neck fat & 0.517 & 0.179 & 0.373 & 0.439 & 0.561 \\
\% of variance & 50.54 & 10.73 & 5.63 & & \\
Description & Boneless & Bone & Wing fat & & \\
\hline
\end{tabular}

$\dagger$ Data from Shahin [28].

\subsubsection{Shared variability}

The results indicate that about $38 \%$ to $91 \%$ of the variation in muscling, fatness and bone traits were brought about by common factors, whereas $9 \%$ to $62 \%$ of their variation were contributed by unique factors specific for each trait (Tab. III). The communalities (the amount of variance in a variable which can be attributed to common factors) for muscle traits ranged from 0.60 for neck muscle to 0.91 for the hind leg muscle. For bone traits they ranged from 0.38 for the neck bone to 0.87 for the hind leg bone, and for fat traits they ranged from 0.41 for loin fat to 0.69 for neck fat (Fig. 2). The neck bone and loin fat had the lowest communality with the greatest unique variances. About $38-41 \%$ of the variation in the neck bone and loin fat was brought about by common factors, whereas 59-62\% of their variations were contributed by a unique factor specific for each neck bone and loin fat. Shahin [26] found that with ducks within the breast, wing and thigh, the communality of muscle was higher than that of bone, but within the drumstick and neck the communality of bone was higher than that of muscle.

As was expected, the shared variability of structural tissues (muscle and bone) was higher than that of fatty tissue. At the level of both limbs (fore and hind limbs), communality of muscle was higher than that of bone which in turn was higher than that of fat. In the Japanese quail, within the hind 
Figure 2. Communalities for each variable in New Zealand White rabbits, Pekin ducklings and Japanese quails.

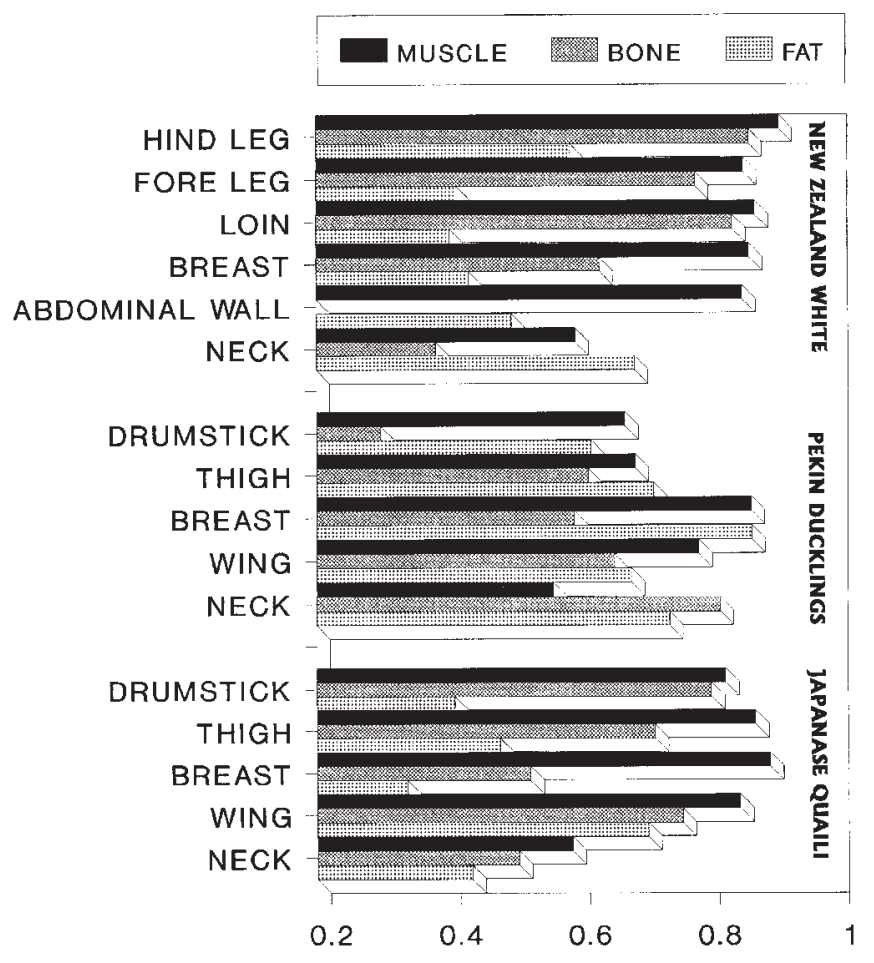

leg (drumstick and thigh), the communalities of muscle and bone were higher than that of fat (Tab. V), while in Pekin ducklings, the communalities of muscle and fat were higher than that of bone (Tab. IV). It appeared that the patterns of shared variability of muscling, fatness and bone traits of the hind leg and breast in the Japanese quail were similar to those found in New Zealand White rabbits. Similarly, at the caudal level (loin) and at the cranial level (breast), communality of fat was lower than that of bone, which in turn was higher than that of muscle. On the contrary, at the neck level, communality of fat was higher than that of muscle, which in turn was higher than that of bone (Fig. 2). In Pekin ducklings, the communality of neck muscle was lower than those of neck bone and neck fat (Tab. IV). While in rabbits, the communality for neck bone was lower than those of neck muscle and neck fat and in the Japanese quail the communality for neck fat was lower than those of neck muscle and neck bone (Tab. V).

\subsection{Independent factor scores and their relationship with total side muscle, total side bone and total side fat weights}

The correlation between the first factor (FC1) and total side muscle weight was 0.89 and that with the total side bone was 0.97 while the correlation between the second factor (FC2) and total side fat weight was 0.892 . In a study on chickens, Ricard and Rouvier [24] found that genetic correlations between the first (size) and second (compactness) factors and muscle/bone deviation were 0.22 and 0.34 respectively. In Pekin ducklings, the correlation between the first factor (fatness) and total side fat 
weight was 0.97 , that between the second factor (muscling) and total side muscle was 0.93 , while that between the third factor (bone) and total side bone was 0.81 (untabulated). In the Japanese quail, the first factor (boneless) was positively correlated with the total carcass muscle $(r=0.90)$ and total carcass fat $(r=0.61)$ and the second factor (bone) was positively correlated with the total carcass bone (untabulated).

The fatless factor score (FC1) alone accounted for $80 \%$ of the variation in total side muscle weight. The results of a stepwise multiple regression of total side muscle weight on the three varimax factor scores (Tab. VI) showed that $R^{2}$ increased from 0.93 to 0.95 and RSD of the estimate decreased from 23.27 to $19.11 \mathrm{~g}$ as FC2 and FC3 orthogonal factor scores were added in stepwise. The final multiple regression equation for the estimation of total side muscle weight from the independent factor scores is:

Total side muscle $(\mathrm{g})=367.73+77.42 \mathrm{FC} 1$ $+31.30 \mathrm{FC} 2+13.29 \mathrm{FC} 3$.

Also, the fatless factor score (FC1) alone accounted for $94 \%$ of the variation in total side bone weight. The results of a stepwise multiple regression of total side bone weight on the three varimax factor scores (Tab. VI) showed that $R^{2}$ increased to 0.95 and the $\mathrm{RSD}$ of the estimate decreased to $2.65 \mathrm{~g}$ as the FC2 orthogonal factor score was added. The final multiple regression equation for estimating total side bone weight from the independent factor scores is:

Total side bone weight $(\mathrm{g})=$ $69.59+11.39 \mathrm{FC} 1+1.44 \mathrm{FC} 2$.

The fatness factor score alone accounted for $81 \%$ of the variation in total side fat weight. The results of a stepwise multiple regression of total side fat weight on the three varimax factor scores (Tab. VI) showed that $R^{2}$ increased from 0.92 to 0.97 and RSD of the estimate decreased from $1.79 \mathrm{~g}$ to $1.05 \mathrm{~g}$ as the FC3 and FC1 orthogonal factor scores were added in stepwise. The final multiple regression equation for estimating total side fat weight from independent factor scores was:

Total side fat weight $(\mathrm{g})=14.63+5.52 \mathrm{FC} 2$ +2.04 FC3 + 1.42 FC1.

The results obtained showed that the regression coefficients in a step-wise multiple regression of total side muscle, total side fat and total side bone against the three orthogonal varimax factors were stable and did not change with the addition of variables in the equation. Corresponding regression coefficients obtained from regressing total side muscle, total side fat and total side bone on original intercorrelated variables (nonorthogonal) were unstable, sensitive to the addition of variables and dependent on which regressors were used in the models. Such instability rendered the estimation of the unique effects of individual variables in the regression equation impossible and therefore to a poor prediction of the independent data set.

In conclusion, the factor analysis technique explores the interdependence of the original 17 muscling, fatness and bone traits by analyzing them simultaneously rather than individually and helps to summarize and explain the correlation patterns among these interdependence traits in terms of three interpretable common factors. The use of orthogonal muscling, fatness and bone composite traits derived from factor analysis were more appropriate than the use of the original interrelated traits for predicting total muscle weight, total fat weight and total bone weight because multicollinearity of two or more independent variables causes the misestimation of the coefficients of such variables. In rabbits, structural tissues (muscular and bone) and fatty tissue were subject to independent determination, while in the Japanese quail, soft tissues (muscular and fatty) and the skeletal support system (bone) were subject to independent determination. In Pekin ducklings, there were three clear distinct factors operating separately on fatness, muscling and bone traits. 
Table VI. Stepwise multiple regression of total carcass muscle, total carcass fat and total carcass bone (g) on original muscling, fatness and bone traits and on their orthogonal traits in the New Zealand White rabbit.

\begin{tabular}{|c|c|c|c|c|c|c|}
\hline Step & $\begin{array}{l}\text { Independent } \\
\text { variables } \\
\text { (predictors) }\end{array}$ & Intercept & $\begin{array}{l}\text { Regression } \\
\text { coefficient }\end{array}$ & SE & $R^{2}$ & $\begin{array}{l}\text { Residual } \\
\text { standard } \\
\text { deviation }\end{array}$ \\
\hline \multicolumn{7}{|c|}{ (i) Original muscling traits as independent variables } \\
\hline 1 & Hind leg muscle & 8.02 & 2.54 & 0.07 & 0.970 & 15.23 \\
\hline 2 & $\begin{array}{l}\text { Hind leg muscle } \\
\text { Breast muscle }\end{array}$ & 17.56 & $\begin{array}{l}1.81 \\
1.51\end{array}$ & $\begin{array}{l}0.12 \\
0.23\end{array}$ & 0.985 & 10.91 \\
\hline 3 & $\begin{array}{l}\text { Hind leg muscle } \\
\text { Breast muscle } \\
\text { Loin muscle }\end{array}$ & 24.90 & $\begin{array}{l}1.11 \\
1.37 \\
1.31\end{array}$ & $\begin{array}{l}0.10 \\
0.13 \\
0.13\end{array}$ & 0.995 & 6.05 \\
\hline \multicolumn{7}{|c|}{ (ii) Their orthogonal traits as independent variables } \\
\hline 2 & $\begin{array}{l}\text { FC1, Fatless } \\
\text { FC2, Fat factor }\end{array}$ & 367.73 & $\begin{array}{l}77.42 \\
31.30\end{array}$ & $\begin{array}{l}3.42 \\
3.42\end{array}$ & 0.931 & 23.27 \\
\hline 3 & $\begin{array}{l}\text { FC1, Fatless } \\
\text { FC2, Fat factor } \\
\text { FC3, Boneless neck factor }\end{array}$ & 367.73 & $\begin{array}{l}77.42 \\
31.30 \\
13.29\end{array}$ & $\begin{array}{l}2.82 \\
2.82 \\
2.82\end{array}$ & 0.990 & 19.11 \\
\hline \multicolumn{7}{|c|}{ (iii) Original fatness traits as independent variables } \\
\hline 2 & $\begin{array}{l}\text { Hind leg fat } \\
\text { Breast fat }\end{array}$ & 2.64 & $\begin{array}{l}2.04 \\
1.53\end{array}$ & $\begin{array}{l}0.19 \\
0.16\end{array}$ & 0.894 & 2.05 \\
\hline 3 & $\begin{array}{l}\text { Hind leg fat } \\
\text { Breast fat } \\
\text { Loin fat }\end{array}$ & 1.12 & $\begin{array}{l}1.69 \\
1.41 \\
1.20\end{array}$ & $\begin{array}{l}0.14 \\
0.11 \\
0.17\end{array}$ & 0.949 & 1.43 \\
\hline \multicolumn{7}{|c|}{ (iv) Their orthogonal traits as independent variables } \\
\hline 2 & $\begin{array}{l}\mathrm{FC} 2 \\
\mathrm{FC} 3\end{array}$ & 14.63 & $\begin{array}{l}5.52 \\
2.04\end{array}$ & $\begin{array}{l}0.26 \\
0.26\end{array}$ & 0.919 & 1.79 \\
\hline 3 & $\begin{array}{l}\text { FC2 } \\
\text { FC3 } \\
\text { FC1 }\end{array}$ & 14.63 & $\begin{array}{l}5.52 \\
2.04 \\
1.42\end{array}$ & $\begin{array}{l}0.16 \\
0.16 \\
0.16\end{array}$ & 0.973 & 1.05 \\
\hline $\begin{array}{c}\text { (v) } \mathrm{Or} \\
1\end{array}$ & \multicolumn{5}{|c|}{ (v) Original bone traits as independent variables } & 3.82 \\
\hline 2 & $\begin{array}{l}\text { Hind leg bone } \\
\text { Breast bone }\end{array}$ & 0.69 & $\begin{array}{l}1.77 \\
1.30\end{array}$ & $\begin{array}{l}0.09 \\
0.12\end{array}$ & 0.973 & 1.96 \\
\hline 3 & $\begin{array}{l}\text { Hind leg bone } \\
\text { Breast bone } \\
\text { Loin bone }\end{array}$ & 1.53 & $\begin{array}{l}1.28 \\
1.12 \\
1.45\end{array}$ & $\begin{array}{l}0.08 \\
0.08 \\
0.18\end{array}$ & 0.989 & 1.26 \\
\hline \multicolumn{7}{|c|}{ (vi) Their orthogonal traits as independent variables } \\
\hline 2 & $\begin{array}{l}\text { FC1 } \\
\text { FC2 }\end{array}$ & 69.59 & $\begin{array}{r}11.39 \\
1.44\end{array}$ & $\begin{array}{l}0.39 \\
0.39\end{array}$ & 0.952 & 2.65 \\
\hline
\end{tabular}

Each variable added for each equation adds an amount $(P<0.05)$ of explained variance. $\mathrm{FC} 1=$ fatless factor; $\mathrm{FC} 2=$ Fatness factor; $\mathrm{FC} 3=$ Boneless neck factor. 


\section{REFERENCES}

[1] Barton R.A., Kirton A.H., The leg and loin as indices of the composition of New Zealand lamb and mutton carcasses, NZ J. Agric. Res. 1 (1958) 783-789.

[2] Blasco A., Estany I., Baselga M., Prediction of rabbit meat and bone weight using carcass measurements and sample cuts, Ann. Zootech. 33 (1984) 161-170.

[3] Blasco A., Ouhayoun J., Masoero G., Study of rabbit meat and carcass criteria and terminology, J. Appl. Rabbit Res. 15 (1992) 775-786.

[4] Bochno R., Lewczuk A., Janiszewska M., The suitability of some live and carcass measurements for the evaluation of carcass quality of rabbits, Rocz. Nauk. Zootech. 6 (1979) 175-183.

[5] Cock A.G., Genetical aspects of metrical growth and form in animals, Quart. Rev. Biol. 41 (1966) 131-190

[6] Cole D.J., White M.R., Hardy B., Carr J.R., Tissue growth in the pig, Anim. Prod. 22 (1976) 341-351

[7] Darton R.A., Rotation in factor analysis, Statistician 29 (1980) 167-194.

[8] Deltoro J., López A.M., Development of commercial characteristics of rabbit carcasses during growth, Livest. Prod. Sci. 15 (1986) 271-283.

[9] El-Hindaway M.M., Yamani K.A., Eskandar E.G., Growth performance, carcass traits and digestibility of rabbits as affected by breed and form of diet under Egyptian environmental conditions, Egypt. J. Rabbit Sci. 2 (1992) 185-196.

[10] Fl'ak P., Granát J., Zelnik J., Genetic and phenotypic correlations among carcass traits in rabbits, Zivoč. Vyroba 24 (1979) 923-932.

[11] Goss R.J., Physiological adaptation of growth, Comp. Anim. Nutr. 4 (1981) 1-32.

[12] Jackson T.H., Relative weight changes in the tissues of the gigot joint as Scottish Blackface castrated male lambs develop from weaning to maturity and an analysis of the observed variation, Anim. Prod. 11 (1967) 409-417.

[13] Janieri A., The nutritive quality of rabbit meat, Riv. Coniglicolt. 24 (1987) 27-29.

[14] Krogmeier D., Dazpo V., Performance traits of New Zealand White and Giant Silver rabbits and their reciprocal crosses. Heterotic effects on carcass yield and composition and meat quality, Arch. Geflugelk. 55 (1991) 162-169.

[15] Lewczuk A., Janiszewska M., Szczepanik G., Bochno R., Regression equations to estimate the content of meat and bones in the carcasses of Danish White rabbits, Acta Acad. Agric. Tech. Olsteniensis Zootech. 35 (1992) 29-42.

[16] Lukefahr S., Hohenboken W.D., Cheeke P.R., Patton N.M., Carcass and meat characteristics of Flemish Giant and New Zealand White purebred and terminal cross rabbits, J. Anim. Sci. 54 (1982) 1169-1174.

[17] Lukefahr S., Hohenboken W.D., Cheeke P.R., Patton N.M., Appraisal of nine genetic groups of rabbits for carcass and lean yield traits, J. Anim. Sci. 57 (1983) 899-907.

[18] Lukefahr S.D., Ozimba C.E., Prediction of carcass merit from live body measurements in rabbits of four breed-types, Livest. Prod. Sci. 29 (1991) 323-334.

[19] Niedźwiadek S., Using regressions for evaluation of meat, bone and fat in the carcasses of New Zealand White rabbits, Rocz. Nauk. Zootech. 7 (1980) 171-180.

[20] Niedźwiadek S., Phenotypic and genetic correlations among some production characters of New Zealand White rabbits, Rocz. Nauk. Zootech. 10 (1983) 37-45.

[21] Ouhayoun J., Comparative development of the body composition of rabbits of three genetic types during postnatal growth, Reprod. Nutr. Dev. 20 (1980) 949-959.

[22] Parigi-Bini R., Xiccato G., Cinetto M., Dalle Zotte A., Converso R., Effect of age, slaughter weight and sex on carcass and meat quality in rabbits. Results on slaughter and carcass quality, Zootec. Nutr. Anim. 18 (1992) 157-172.

[23] Reddy N.Y., Rao D.R., Chen C.P., Comparative performance of rabbits and broilers, Nutr. Rep. Int. 16 (1977) 133-137.

[24] Ricard F.H., Rouvier R., A study of conformation measurements in the fowl. IV. Genetic variability of carcass measurements and meat/bone deviation in Bresse-Pile cockerels, Ann. Zootech. 15 (1966) 197-269.

[25] SAS, SAS User's Guide, Statistical Analysis System Institute, Inc., Cary, NC, USA, 1988.

[26] Shahin K.A., Analysis of muscle and bone weight variations in an Egyptian strain of Pekin ducklings, Ann. Zootech. 45 (1996) 173-184.

[27] Shahin K.A., Selection indexes using live measurements or their varimax rotated factors for improving meat weight distribution- Application on carcasses of Pekin ducks, Arch Geflugelk. 60 (1996) 103-108.

[28] Shahin K.A., Sources of shared variability in muscle and bone weight distribution and estimation of carcass meatiness and bone utilizing orthogonal carcass traits derived from factor analysis in Japanese quail, Ann. Zootech. 46 (1997) 175-183.

[29] Shahin K.A., Sources of shared variability in muscle and fat weight distribution in Pekin ducklings, Ann. Zootech. 48 (1999) 59-66.

[30] Shahin K.A., Soliman A.M., Moukhtar A.E., Sources of shared variability for the Egyptian buffalo body shape (conformation), Livest. Prod. Sci. 36 (1993) 323-334. 
[31] Tanner J.M., Burt A.W.A., Physique in the infrahuman mammalia: A factor analysis of body measurements of dairy cows, J. Genet. 52 (1954) $36-51$.

[32] Varewyck H., Bouquet Y., Relationship between tissue composition of meat rabbit carcasses and that of their principal portions, Ann. Zootech. 31 (1982) 257-268.

[33] Varewyck H., Bouquet Y., Zeveren A. van, A progeny test for carcass quality in meat rabbits, Arch. Geflugelk. 50 (1986) 26-31.

[34] Varewyck H., Lampo P., Bouquet Y., 2. Sélection. 2.2. Recherche sur l'hérédité de paramètres zootechniques de la race du Blanc de Termonde, Rev. Agric. 40 (1987) 1143-1153.

[35] Varewyck H., Lampo P., Bouquet Y., Zeveren A. van, Inheritance of carcass quality in broiler rabbits, Vlaams Diergeneesk. Tijdschr. 56 (1987) 348-351.

[36] Vicente J.C., Peris J.L., Viudes de Castro P., Prediction equations in rabbit growth studies, ITEA, Inform. Téc. Econ. Agrar. 20 (1989) 26-37.

[37] Wright S., General, group and special size factors, Genetics 17 (1932) 603-619. 